\title{
DÜBLIN
}

Technological University Dublin

ARROW@TU Dublin

\section{Strategic Partnerships and the Internationalisation Process of Software SMEs}

\author{
Aileen Kennedy \\ Technological University Dublin, aileen.kennedy@tudublin.ie \\ Kathy Keeney \\ Technological University Dublin
}

Follow this and additional works at: https://arrow.tudublin.ie/buschmarcon

Part of the Marketing Commons

\section{Recommended Citation \\ This Conference Paper is brought to you for free and open access by the School of Marketing at ARROW@TU Dublin. It has been accepted for inclusion in Conference papers by an authorized administrator of ARROW@TU Dublin. For more information, please contact arrow.admin@tudublin.ie, aisling.coyne@tudublin.ie, gerard.connolly@tudublin.ie.}

Kennedy, A., Keeney, K.: Strategic Partnerships and the Internationalisation Process of Software SMEs. European International Business Academy (EIBA) Conference, December 7-9, Fribourg, Switzerland, 2006.

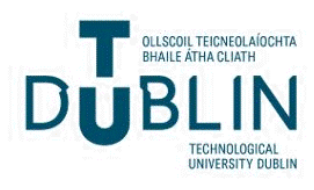


STRATEGIC PARTNERSHIPS AND THE INTERNATIONALISATION

PROCESS OF SOFTWARE SMES

Aileen Kennedy

Lecturer in Services Marketing

School of Marketing

Faculty of Business

Dublin Institute of Technology (DIT)

Aungier Street, Dublin 2

Ireland

Ph 0035314027150

Email aileen.kennedy@dit.ie

Corresponding \& presenting author
Kathy Keeney

Research Student

School of Marketing

Faculty of Business

DIT

Aungier Street, Dublin 2

Ireland

Kathy.keeney@dit.ie

\begin{abstract}
This research investigates the strategic partnering activities of software SMEs (small to medium sized enterprises), their motivations to engage in strategic partnerships as part of the internationalisation process, the key benefits achieved and the main challenges encountered. A qualitative research methodology focusing on Irish indigenous firms is used. Findings suggest that strategic partnerships were initiated to take advantage of firm synergy, reputation and credibility advantages. Partnerships also served as an important foreign market entry mechanism allowing firms to accelerate sales cycles and reduce risk in overseas markets. Challenges facing firms
\end{abstract}


included partner selection and issues of control. Directions for further research are highlighted.

\section{Introduction}

In an increasingly competitive environment often characterised by larger firms with access to plentiful resources, the ability of SMEs to survive and expand their business hinges on the formulation of appropriate competitive strategies. One such option is participation in strategic partnering, which has become an increasingly popular method of conducting business in overseas markets (BarNir \& Smith, 2002). GarcíaCanal et al., (2002) suggest that firms choose strategic partnerships both to speed up the internationalisation process and also to improve their international competitiveness through economies of scale, risk reduction and learning new abilities. The development of these partnerships is therefore an important element of the firm's strategic foundation which may allow it to supplement strategic blind spots in internationalisation activities (Welch \& Welch, 1996).

In the case of the smaller software firm, globalisation forces and a requirement to operate in niche markets may necessitate the use of strategic partnering arrangements in overseas markets. Elmuti \& Kathawala (2001, p. 214) highlight that "in order to compete in the growing international market, it will be increasingly necessary for firms to cooperate on a global level and continually build international relationships which will facilitate the process of global competition". This occurs through the exploitation of the intrinsic advantages which strategic partnering can offer the internationalising software firm. 
Although strategic partnerships have been extensively covered within the literature, there is a paucity of research investigating strategic partnerships from the business and international competitiveness perspective of SMEs and small high-technology firms. This paper seeks to address this gap in research activity by investigating strategic partnering activities in the internationalisation process of software SMEs. Strategic partnering literature is reviewed and an overview of the Irish software sector is presented. The qualitative research methodology is outlined, key findings are presented and directions for future research are highlighted.

\section{Literature Review}

This review is based on the theoretical paradigm of strategic choice in examining partnerships as part of the wider literature dealing with inter-organisational relationships. A pervasive theme within this literature is whether such activities make sense for firms and whether the advantages outweigh the disadvantages (Barringer \& Harrison, 2000). This review examines definitions of strategic partnerships, challenges posed and why such partnerships make sense for firms.

Within the area of inter-organisational relationships strategic partnerships are defined as "the pooling of specific resources and skills by cooperating organisations in order to achieve common goals, as well as goals specific to the individual partners" (Varadarajan \& Cunningham, 1995, p. 282) while retaining their separate entities. Parkhe (1993) reiterates this view of the strategic partnering process as consisting of the development of cooperative agreements or arrangements, necessitating 
connections and linkages in the utilisation of resources and/or authority mechanisms from independent firms, in order to jointly accomplish individual firm objectives.

A strategic partnership can generally be defined as "an informal or formal arrangement between two or more companies with a common business objective" (Czinkota \& Ronkainen, 1995, p. 456) or likewise as an agreement between firms to do business together in ways that go beyond normal company to company dealings, but falls short of a merger or full partnership (Wheelen \& Hungar, 2000). Partnerships can range from informal handshake agreements to formal agreements with lengthy contracts (Elmuti \& Kathawala, 2001). The businesses' decision to compete by forming partnerships rather than pursuing alternatives such as acquisition, merger or internal development constitutes a strategic choice the goal of which is seeking competitive advantage through cooperation with other firms (Xie \& Johnson, 2004).

\section{Strategic Partnership Dynamics and Challenges for Firms}

Strategic partnering may be initiated with well-known and established firms (Kauffman, 1995), domestic firms or suitably knowledgeable local firms in overseas markets (Lu \& Beamish, 2001). Various forms of strategic partnering exist, for example García-Canal et al., (2002) identify three forms of strategic partnering activities and cooperative internationalisation strategies; one key global alliance, multiple global alliances and competence-building alliances. In addition to these forms of strategic partnerships, marketing and technology partnerships also exist (Das et al., 2003). Within these different varieties and forms of strategic partnership arrangements there are also differing levels of partner relations; from weak relationships, to strong 
close knit bonds between firms, each of which provide a variety of opportunities for each firm (Kanter, 1994).

Firms which engage in higher levels of coordination activities are increasingly likely to have successful strategic partnerships with other firms, resulting in higher levels of trust, sincerity, identification of common goals and successful communication in the form of quality information exchange (Elg \& Johansson, 2001; Kauser \& Shaw, 2004). Therefore, building trust between firms is one of the most important aspects of strategic partnerships (Frankel et al., 1996; Elmuti \& Kathawala, 2001). The underlying dynamics of this trust in interpersonal relationships is also based on learning (Steensma et al., 2000; Harris \& Wheeler, 2004) and is directly influenced by national culture (Mehta et al., 2006).

In addition, issues of trust are also dependent upon people and the relationship between firms and managers (Elmuti \& Kathawala, 2001). The dynamic of human relationships suggests this process is multifaceted and unpredictable, as strategic partnering activities obviously occur in social contexts (Eisenhardt \& Schoonhoven, 1996; Steensma et al., 2000) and involve social networks, both of which facilitate the development and maintenance of strategic partnerships (BarNir \& Smith, 2002). Strategic partnership development also hinges on management commitment to the activity. This commitment is affected by fears of loss of control (Elmuti \& Kathawala, 2001), differences in management style, the delegation of responsibility and formal or informal control procedures (Parkhe, 2001). 
Strategic partnerships consist of a delicate balance between issues of control and the requirement to maintain an amicable relationship between firms and managers (Kauser \& Shaw, 2004). Tension between knowledge protection and knowledge sharing may be of concern between parties, particularly if the relationship is reliant on active information sharing and learning (Jordan, 2004). Finding appropriate and suitable strategic partners also poses a challenge to internationalising firms (Karagozoglu \& Lindell, 1998; García-Canal et al., 2002) in the form of goal conflicts between parties, disagreement regarding control divisions and cultural incongruity (Frankel et al., 1996; Elmuti \& Kathawala, 2001; Lu \& Beamish, 2001).

Effective communication between parties is extremely important, yet language, cultural differences (Elmuti \& Kathawala, 2001; Parkhe, 2001) and interfirm diversity may impinge upon the process (Parkhe, 2001). Additionally, firms are susceptible to instability, or an unplanned change within the partnership, which may also result from shifts in bargaining power between parties (Inkpen \& Beamish, 1997). Differences in organisational size may also result in one firm exerting negative power effects on the other (Elg \& Johansson, 2001). Therefore flexible arrangements in strategic partnering are particularly important as partners often have to deal with diverse environments and unforeseen circumstances (Aulakh et al., 1996).

\section{Why Strategic Partnering Makes Sense for Small High-Technology Firms}

Despite the challenges facing firms engaging in strategic partnerships they appear to make sense for many small high-technology firms. Elmuti \& Kathawala (2001, p. 207) note that "for many small companies strategic partnering activities are the only way 
they can stay competitive and even survive in today's technologically advanced, everchanging business world" where strategic partnering is seen as an essential ingredient in international firm strategy (Duysters \& Hagedorn, 1996). Strategic partnerships can provide such functions as marketing, networking and the provision of knowledge (Harris \& Wheeler, 2004) and since smaller firms generally suffer from resource constraints in overseas markets, such relationships make international expansion possible (Coviello \& Munro, 1997; Jones, 1999; Harris \& Wheeler, 2004).

Strategic partnerships contribute to the increased strength of firms operating in overseas markets through advantages of complementary expertise, competitive advantage and increased bargaining power (Lee et al., 2000). Partnerships can be used by SMEs to build on innovative capability and technological competence, overcome weaknesses such as poor financial position or low levels of expertise in production, marketing and management (Jarratt, 1998) and to access alternative methods of serving customers (Elmuti \& Kathawala, 2001). The firm may gain access to embedded knowledge or skills of their strategic partner (Inkpen \& Beamish, 1997) permitting the smaller firm to increase market strength, visibility and credibility, and improving its international competitiveness (García-Canal et al., 2002). In an interesting extension to the concept of smallness, Narula \& Hagedoorn (1999) suggest that small country firms will show a higher propensity than larger country firms to engage in international strategic partnerships as local demand is insufficient to achieve economies of scale.

Forming a strategic partnership with another firm already present in a foreign marketplace is seen as an appealing alternative to seeking entry alone (Elmuti \& 
Kathawala, 2001) providing entry doorways into successive foreign countries or firms and also diminishing the possibility of firms making mistakes in unfamiliar foreign markets (Lu \& Beamish, 2001). Therefore, strategic partnering means that smaller firms are empowered to carry out larger projects with less financial commitment, as the financial burden of seeking new overseas markets may be too great for an individual firm to bear alone (Elmuti \& Kathawala, 2001).

High technology-based firms have demonstrated the use of relationships in sustaining international growth (Coviello \& Munro, 1995; Jones, 1999) and competitive advantage (Spence, 2004) implying that strategic partnering relationships between firms are influential throughout the internationalisation process. A software firm's strategic partner may permit the firm to offer a more complete solution to the end customer (Moen et al., 2004) and provide localisation or other development assistance. Consequently, it may be said that strategic partnerships have the potential to "change the strategic direction of the firm" (Harris \& Wheeler, 2004, p. 18) in international markets. Accordingly, strategic partnering activities should be considered as competitive weapons in international software markets (Drago, 1997).

Though strategic partnering is seen as an integral part of international business competitive advantage (Kanter, 1994) limited research exists examining partnering activities of SMEs in high-technology sectors. Forrest (1990) examined the strategic partnerships adopted by small high-technology firms and generated a guide to the types of partnerships appropriate for building specific skills and resources. Drago (1997) also examined the use of strategic partnerships in the Information Technology industry and proposed that small companies are more likely to enjoy the benefits of 
strategic partnerships than larger companies as they are more likely to suffer from a lack of resources, are more likely to be threatened by competitive uncertainty and to inhabit volatile environments that create marketing uncertainty. Strategic partnerships can be used to decrease these many areas of uncertainty. Companies competing in highly innovative industries or industry segments are also more likely to benefit from strategic partnerships as such highly innovative industries will have greater market and operational uncertainty (Drago, 1997).

\section{An Overview of the Irish Software Sector}

Despite Ireland's spectacular success in attracting inward investment from multinational software companies, the ability of indigenous companies to become international players is vital for the continued success of the local software industry. This opinion is informed by research conducted by the Irish Software Association (ISA) which concluded in 2003 that the Irish software sector was on the verge of becoming irrelevant on the global stage. At the end of 2003, the indigenous Irish software sector had approximately 860 firms whose internationalisation activities accounted for $€ 1.1 \mathrm{bn}$ (ISA, 2005a). The vast majority of firms are located in the Dublin region. The sector is characterised by large numbers of firms engaging in internationalisation due to overseas market opportunity and limited domestic market size. Ireland currently has a promising indigenous software sector employing 16,000 people with the potential to employ 50,000 and deliver annual revenue to the economy of $€ 7.5$ bn by 2010 (NSD, 2005). 
As such, the indigenous software industry exhibits unique characteristics such as high levels of productivity, innovation and increasingly export-led behaviour from inception (Crone, 2002). However these companies are small and experience difficulties in growing revenue at the rate needed to compete in global markets. Currently just 10 percent of home grown software companies have annual revenues in excess of $€ 10 \mathrm{~m}$ and half of all companies in the sector have revenue of less than $€ 2 \mathrm{~m}$ (ISA, 2005b). Though Ireland remains the world's number one software exporter, with annual exports worth $€ 14 \mathrm{bn}$, the vast majority of sales come from multinationals investing in Ireland.

The idea that Ireland's indigenous software sector is too small and is struggling to make inroads into international markets is a theme repeatedly highlighted by the Irish Software Association (ISA) which suggests that "to achieve true international scale companies need to have revenues approaching the $€ 50 \mathrm{~m}$ mark" (Cullinan, 2005) and to achieve this goal they need to consider partner strategies. The situation is compounded by increased competition from emerging low cost software economies such as India and Israel which poses a significant challenge for the sector as it forces the country to raise its game with immediate effect. To achieve the necessary critical mass to compete on an international scale, firms must leverage strategic partnerships as facilitators and enablers of market entry and international development. Indigenous firms need to further engage in strategic partnering and networking activities with companies offering a broad range of hardware and software services in order to capitalise on future growth within the global software market (Anon, 2004). Despite the recognition from industry bodies and practitioners that strategic partnering 
activities are a vital and unique attribute of the software industry (Crone, 2002) their influence has been largely neglected from a national research perspective.

\section{Research Methodology}

This research addresses the lack of knowledge and data in relation to strategic partnering activities in the small high-technology firm sector, as illustrated by the software sector from which the sample is drawn. The research objectives are (a) to examine the extent of strategic partnering activity within local software firms (b) to investigate firm motivations for engaging in strategic partnering (c) to examine the benefits achieved by firms and (d) the challenges encountered to date.

Qualitative research was considered suitable for such a process based study (QuinnPatton, 2002) and the use of qualitative interviewing was considered a suitable technique to "get inside" this process to understand firm experiences (Shaw, 1999). This type of qualitative research approach usually signals the use of small samples, selected purposefully to facilitate the inclusion of information rich cases (Shaw, 1999; Quinn-Patton, 2002). This research is based on ten indigenous software firm's selected using non-probability judgemental sampling to generate a sample representative of the population of interest. This data is part of a larger research project investigating the internationalisation of software firms on a longitudinal basis and this impacts the sampling methodology employed.

To ensure that firms participating in the research possessed a desired level of information richness, a set of predetermined criteria (Shaw, 1999) was used. The unit 
of analysis adopted was owner/managers of firms to ensure access to interviewees. Employee turnover at other managerial levels in the sector tends to be high. The vast majority of indigenous software firms, over 75 percent, are located in the Dublin area (Crone, 2002) and engage predominantly in business-to-business activities and the sample is drawn from this group. All sample firms are SMEs employing less than 250 people (European Commission, 2005).

Within the indigenous software sector approximately 40 percent of firms generate revenue in the $€ 2-10 \mathrm{~m}$ range with 10 percent breaking the $€ 10 \mathrm{~m}$ barrier. The other 50 percent generate revenue of less than $€ 2 \mathrm{~m}$ and are categorised as micro firms (European Commission, 2005). This sample draws from the 40 percent of firms in the $€ 2-10 \mathrm{~m}$ revenue band. As part of an ongoing research project this approach was taken in an effort to increase the chances of sample firm's survival, as the research is longitudinal in nature.

\section{Research Limitations}

The research methodology acknowledges the limitations inherent within qualitative research such as arguments against validity and generalisation of findings. The use of a single service sector implies that the findings may not be applicable to other internationally traded services without further empirical validation. The selection of firms with higher turnover introduces a sample bias towards more successful firms but does not impact the size of firms included, all of which are SMEs. The research excludes micro firms in the sector and sampling Dublin based firms effectively excludes 25 percent of firms located in other regions around Ireland. 


\section{Research Findings}

\section{Strategic Partnering Activity}

The sample, Companies A-J, represents diversity within the sector including a range of software offerings from pharmacy solutions (A), business integration services (B), spatial technology (C), localisation services (D), insurance (E), mobile and wireless (F), platform technologies $(\mathrm{G})$, fraud, risk management and CRM (H), logistics management (I) and online accommodation booking sectors (J). Respondent firm profiles are presented in Appendix 1. Nine of the ten sample firms were engaged in some form of strategic partnering activities, which generally involved collaboration with fellow industry players, suppliers, global hardware vendors and local or international firms. The exception is Company $G$ where a downturn in the mobile payments sector negatively impacted the firm's plans for strategic partnerships. All sample firms qualify as SMEs with employee numbers ranging from 24-80 with two firms employing 150 (D) to 210 (E) people.

Both verbal and written agreements supporting alliances emerged from the data and within the sample there is evidence of differing types of partnership agreements between firms, both formal $(\mathrm{C}, \mathrm{F})$ and informal $(\mathrm{J}, \mathrm{D})$ in nature. Company $\mathrm{C}$ felt strongly that partnership agreements should contain elements of a formal relationship in terms of financial commitment so that both parties are committed to ensuring the relationship has a positive and mutually beneficial outcome. On the other hand Company $\mathbf{J}$ veers towards informal agreements fearing that potential partners might “run away because they don't want to get involved” in overly complex formal 
agreements. The firm believes that such an informal approach promotes client confidence and encourages trust in the relationship.

Central to these agreements firms recognise the importance of maintaining the interpersonal relationship underpinning strategic partnering activities (H,I,F) and the value of such relationships that are often driven from previous business opportunities and contacts. Firms also valued the ability to access their strategic partner's network, which provided increased mechanisms and opportunities for further internationalisation activities. Firms also acknowledged strategic partnerships as key assets to the firm $(\mathrm{B}, \mathrm{C}, \mathrm{E})$ and maintain that strategic partners contribute to the learning function of the firm (E) and therefore influence the long-term vision of the firm.

\section{Motivations For Partnership Participation And Benefits Achieved}

In examining the strategic motivations of firms engaging in partnership agreements the key strategic intent of building current business capability as proposed by Jarratt (1998) was applied. This incorporates the motivations of firms to build business knowledge, expertise and skills; access new client groups and access resources required for specific client groups. A key theme of this research was the firm's desire to build business knowledge and expertise via information exchange. Most firms engaged in information exchange with partners whether through active information sharing with strategic partners on potential customers and market developments (A) or by participating in informal networking activities (I, H) some of which occur through seminars and conferences (D). Informal networking activities prove useful in terms of practical and commonplace business information and activities. Such information 
sharing may also be for market entry preparation (A) or geared towards ongoing exchanges vis-à-vis competitors and joint market targeting campaigns (E).

Such exchanges allowed Company B to scrutinise the international experiences of other firms and incorporate this knowledge into the firm, particularly in terms of making and renewing international contacts and approaching overseas companies. Company D participates in active information sharing and resource-planning activities with its partners. This creates loyalty on the part of suppliers and enhances the credibility of the firm in terms of prospecting potential customers. Company $\mathrm{H}$ also undertakes informal networking with strategic partners and former clients to access tactical contact information to pave the way for an approach to foreign offices or subsidiaries of existing clients. This is a valuable means of increasing the firm's international profile.

Despite general agreement that for the relationship to function both participants should engage in reciprocal information sharing, not all respondents view information exchange in a positive light with Company $\mathrm{C}$ very reluctant to make complete disclosure to strategic partners in order to protect and retain its competitive advantage.

\section{Reputational Benefits By Association With Partners}

A key outcome for sample firms has been the benefits delivered by association with strategic partners leading for example to enhanced firm credibility and reputation (A, C, D, E, F) increased firm confidence $(F)$ and the perception of increased customer trust and confidence $(\mathrm{J})$ in the company. Strategic partnering can capitalise on 
potential synergies between participants and can bring confidence to the firm, as both partners appear larger $(\mathrm{F})$, well funded and robust when seeking entry to larger companies such as multinationals. Strategic partners have also facilitated increased market presence and visibility; ultimately affecting the firm's sales and branding strategies "it's a way of increasing the brand, market presence, and sales, for some markets it can work very well" (Company C).

Company $\mathrm{H}$ also uses strategic partners as entry mechanisms into overseas firms through the pursuit of partners with appropriate knowledge of overseas target firms. Such a strategy facilitates a quicker and more efficient sales cycle and the creation of sustainable relationships between firms "we would use partners to get us to a willing buyer". The firm believes that strategic relationships should bring reciprocal value to each party. The firm gains accelerated entry and partners derive benefit from offering implementation and other services to both the firm and overseas client. Company $\mathrm{H}$ also commented on a possible future strategy of persuading strategic partners to implement the firm's product within their own organisation. When successful, this brings increased commitment to the partnership and provides important reference sites overseas. In addition, this firm anticipates the implementation of further strategic partnerships along the firm's value chain to include collaboration with distribution partners.

Company E also observes that partnerships are an important learning experience for the firm, as regards internal operations and selling cycles, and in enhancing firm credibility, "we've learned from the experience...they (partners) are an extra pair of eyes looking in. They tell you things about yourself that you may not want to hear". 
However, firms also face a challenge when associated with a much larger partner organisations for example Company E have initiated strategic partnership agreements with global hardware vendors. Due to the size of these organisations, the onus is now on both the firm and its partner to ensure the relationship is visible throughout the organisation, including overseas subsidiaries, and is mutually beneficial.

\section{Challenges Facing Firms Engaging In Strategic Partnering}

A key issue for management trying to build successful alliances is to commit adequate time and resources to nurture such relationships. This can be a drain on company resources and is not always productive as in the case of Company $\mathrm{G}$, which had developed partnership agreements with several large market players to advance international expansion. Unfortunately, these partnerships did not come to fruition due to a downturn in the mobile payments sector that negatively impacted upon the firm's overseas expansion.

Firms also face issues of control and dependence depending on organisation size and resource base. For example Company $\mathrm{E}$ is cautious of partnerships where larger market players may exert undue influence over smaller firms, resulting in an unfair workload distribution. In spite of this, the firm believes that if a good relationship underpins the partnership then the outcome should be favourable for both parties.

The selection of a suitable partner also remains an issue for firms. Potential partners seeming an appropriate technical match may not prove a fitting strategic partner if interpersonal difficulties are present. Firm should seek strategic partners based on 
appropriate market opportunity and strong interpersonal relationships. The experiences of Company F illustrate this issue, "we've tried to partner with companies and on paper it looks like a fit, but the people didn't see eye to eye so we didn't progress with that". Company B also warns of an over reliance on international strategic partnerships, "we've got to go and paddle our own canoe" and maintains that a major challenge for internationalising firms is to find proactive partners who actively seek new opportunities for both firms, "you need to avoid having these lukewarm, what we call "Barney" partnerships, you know, I love you, you love me but it's a challenge to get one (partner) who's a proactive one rather than a reactive one, the challenge is to get the right one”.

\section{Conclusions and Research Implications}

Coviello and Munro (1995; 1997) and Kauffman (1995) maintain that formal or informal relationships with other firms is viewed as an effective mechanism for increasing marketing capabilities in existing international markets or as mechanisms to gain entry into new markets. In the case of respondent firms, various partnerships were initiated in order to take advantage of firm synergy, reputation and credibility advantages. These partnerships also served as important foreign market entry mechanisms, allowing firms to accelerate firm sales cycles and reduce risk in overseas markets (Elmuti \& Kathawala, 2001). These forms of partnerships serve to enhance firm credibility, provide entry mechanisms into foreign markets and provide vital local market knowledge (Inkpen \& Beamish, 1997). 
Moen et al., (2004) maintain that strategic partnering activities are an important mechanism for increasing firm competencies and resource base, as strategic partnering facilitates firms to overcome these resource constraints by sharing intangible assets (Lee et al., 2000; Lu \& Beamish, 2001). The findings support these points, as most respondent firms sought to engage in active information sharing and joint marketing activities, involved strategic partners in market entry and used them as mechanisms to enhance reputation; which brought increased confidence and further overseas market credibility.

Though literature on the management of strategic partnership activities highlights challenges in terms of loss of flexibility and issues of trust and control (Frankel et al., 1996; Drago, 1997; Elmuti \& Kathawala, 2001) the feedback from respondent firms regarding partnering activities was mostly positive with the exceptions cited. This may be partially attributable to the sample selection and also to the fact that the majority of respondent firms were aware of the need to maintain the interpersonal relationships (Harris \& Wheeler, 2004) underpinning the partnership process. Also as the need to gain local insight and engage in strategic partnering activities overseas is often an immediate one, this partially explains the high levels of commitment to the process displayed by respondent firms.

Due to their relatively recent origin a general understanding of when, where and how to use strategic alliances is not available (Drago, 1997) and this lack of knowledge is pronounced in the case of small firms operating in the high-technology sector. Further sectoral research could examine unsatisfactory or unsuccessful strategic partnering arrangements in the sector with a view to identifying managerial guidelines for firms. 
Also looking at a wider sample of both small and larger firms and a sample of micro firms could provide useful insights into the formation and management of strategic partnerships in the software sector.

For the software sector the imperative to reach a critical mass to compete effectively in fiercely competitive international markets remains. These two factors combine to generate an impetus for further research in this expanding business sector where a more comprehensive understanding of the intricacies of the relationships involved in strategic partnerships would be valuable to academics, practitioners and policy makers alike.

\section{References}

Anon (2004). Ireland's Software Cluster: Preparing for Consolidation. Hot Origin, Dublin. Access via http://www.hotorigin.com

Aulakh, P. S., Kotabe, M. \& Sahay A. (1996). Trust and Performance in Cross-Border Marketing Partnerships: A Behavioural Approach. Journal of International Business Studies, 27(5), 1005-1032.

Barringer B.R. \& Harrison J.S. (2000). Walking a Tightrope: Creating Value Through Interorganizational Relationships. Journal of Management, 26(3), 367-403.

BarNir, A. \& Smith K. A. (2002). Interfirm Alliances in the Small Business: The Role of Social Networks. Journal of Small Business Management, 40(3), 219-232.

Clark M. (2005). ISA unveils blueprint for the software sector. ElectricNews.net. Access via http://www.enn.ie/frontpage/news-9608213.html 
Coviello, N. E. \& Munro H. J. (1995). Growing the entrepreneurial firm: Networking for international market development. European Journal of Marketing, 29(7), 49-61.

Coviello, N. E. \& Munro H. J. (1997). Network Relationships and the Internationalisation Process of Small Software Firms. International Business Review, 6(4), 361-386.

Crone, M. (2002). A profile of the Irish Software Industry, Northern Ireland Economic Research Centre. Belfast, Northern Ireland.

Cullinan B. (2005) Chairperson of the Irish Software Association (ISA) cited in Clark M. (2005). ISA unveils blueprint for the software sector. ElectricNews.net. Access via http://www.enn.ie/frontpage/news-9608213.html

Czinkota M.R. \& Ronkainen I.A. (1995). International Marketing. $4^{\text {th }}$ Edition, Dryden Press.

Das, S., Sen, P. K. \& Sengupta S. (2003). Strategic alliances: a valuable way to manage intellectual capital. Journal of Intellectual Capital, 4(1), 10-19.

Drago, W. A. (1997). When strategic alliances make sense. Industrial Management and Data Systems, 97(2), 53-58.

Duysters, G. \& Hagedorn J. (1996). Internationalisation of corporate technology through strategic partnering: an empirical investigation. Research Policy, 25(1), 1-12.

Eisenhardt, K.M, \& Schoonhoven, C.B. (1996). Resource-based view of Strategic Alliance Formation: Strategic and Social Effects in Entrepreneurial Firms. Organization Science, 7(2), 136-50. 
Elg, U. \& Johansson, U. (2001). International Alliances: how they contribute to managing the inter-organizational challenges of globalisation. Journal of Strategic Marketing, 9(2), 93-110.

Elmuti, D. \& Kathawala Y. (2001). An overview of strategic alliances. Management Decision, 39(3), 205-217.

European Commission (2005). The New SME Definition: User Guide and Model Declaration, Enterprise and Industry Publication. Access via

(http://europa.eu.int/comm/enterprise/enterprise_policy/sme_definition/index_en.htm)

Forrest J.E. (1990). Strategic alliances and the small technology based firms. Journal of Small Business Management, 28(3), 37-45.

Frankel, R., Whipple, J. S. \& Frazer, D. J. (1996). Formal versus informal contacts: achieving alliance success. International Journal of Physical Distribution and Logistics, 26(3), 47-63.

García-Canal, E., Duarte, C. L., Crialdo, J. R. \& Llaneza A. V. (2002). Accelerating international expansion through global alliances: a typology of cooperative strategies. Journal of World Business, 37(2), 91-107.

Harris, S. \& Wheeler, C. (2004). Entrepreneurs' relationships for internationalisation: functions, origins and strategies. International Business Review, 14(2), 187 - 197.

Inkpen, A. C. \& Beamish, P. W. (1997). Knowledge, Bargaining Power and the Instability of International Joint Ventures. Academy of Management Review, 22(1), 177-202. 
ISA (2005a). Background to the Irish Software Industry. Irish Software Association (ISA). Access via http://www.nsd.ie/htm/ssii/back.htm

ISA (2005b). Barriers to Growth, Opportunities to Scale. Irish Software Association access via http://www.isa.ie

Jarratt, D. G. (1998). A strategic classification of business alliances: a qualitative perspective built from a study of small and medium sized enterprises. Qualitative Market Research: An International Journal, 1(1), 39 - 49.

Jones, M. V. (1999). The internationalisation of small high-technology firms. Journal of International Marketing, 7(4), 15-41.

Jordan, J. (2004). Controlling knowledge flows in international alliances. European Business Journal, 16(2), 70 - 77.

Kanter, R. M. (1994). Collaborative Advantage. Harvard Business Review, 72(4), 96108.

Karagozoglu, N. \& Lindell M. (1998). Internationalisation of Small and Medium Sized Technology Firms: An Exploratory study. Journal of Small Business Management, 36(1), 44-60.

Kauffman, F. (1995). Internationalisation Via Co-operation-Strategies of SMEs. International Small Business Journal, 13(2), 27-33.

Lee, K. S., Lim, G. H. \& Tan S. J. (2000). Feasibility of strategic alliance as an entry strategy into markets dominated by major competitors. Journal of Small Business and Enterprise Management, 7(1), 43-57. 
Lu, J. W. \& Beamish, P. W. (2001). The Internationalisation and Performance of SMEs. Strategic Management Journal, 22(6/7), 565-586.

Mehta R., Larsen T., Rosenbloom B. \& Ganitsky J. (2006). The impact of cultural differences in U.S. business-to-business export marketing channel strategic alliances. Industrial Marketing Management, 35(2), 156-165.

Moen, Ø., Gavlen, M. \& Endressen I. (2004). Internationalisation of small, computer software firms. Entry forms and market selection. European Journal of Marketing, 38 (9/10), 1236-1251.

Narula R. \& Hagedoorn J. (1999). Innovating through strategic alliances; moving towards international partnerships and contractual agreements. Technovation, 19(5), 283-294.

NSD (2005). National Software Directorate. Software Industry Statistics for 19912004. Access via http://www.nsd.ie/htm/sii/stat.htm

Parkhe, A. (1993). Strategic Alliance Structuring: A Game Theoretic and Transaction Cost Examination of Interfirm Cooperation. Academy of Management Journal, 36(4), 794-829.

Quinn-Patton, M. (2002). Qualitative Research and Evaluation Methods. Third Edition. Sage Publications, Thousand Oaks, UK.

Shaw, E. (1999). A guide to the qualitative research process: evidence from a small firm study. Qualitative Market Research: An International Journal, 2(2), 59-70. 
Spence, M. (2004). Efficiency and Personalization as Value Creation in Internationalizing High-Technology SMEs. Canadian Journal of the Administrative Sciences, 22(1), 65-78.

Steensma, H.K., Marino L., Weaver, K.M. \& Dickson, P.H. (2000). The influence of national culture on the formation of technology alliances by entrepreneurial firms. Academy of Management Journal, 43(5), 951-973.

Varadarajan P.R. and Cunningham M.H. (1995). Strategic alliances; a synthesis of conceptual foundations. Journal of the Academy of Marketing Science, 23(4), 282296.

Welch, D. E. \& Welch L. S. (1996). The Internationalisation Process and Networks: A Strategic Management Perspective. Journal of International Marketing, 4(3), 11-28.

Wheelen T.L \& Hungar D.J. (2000). Strategic Management and Business Policy. $7^{\text {th }}$ Edition, Addison-Wesley Publishing, New York, USA.

Xie F.T. \& Johnson W.J. (2004). Strategic alliances; incorporating the impact of ebusiness technological innovations. Journal of Business and Industrial Marketing, 19(3), 208-222. 


\section{Appendix 1: Main Characteristics of Respondent Firms}

\begin{tabular}{|c|c|c|c|c|c|c|c|c|c|c|}
\hline & Company A & Company B & Company C & Company D & Company E & Company F & Company G & Company $\mathrm{H}$ & Company I & Company J \\
\hline Business Activity & $\begin{array}{l}\text { Pharmacy } \\
\text { solutions } \\
\text { software }\end{array}$ & $\begin{array}{l}\text { Business } \\
\text { integration } \\
\text { Software }\end{array}$ & $\begin{array}{l}\text { Spatial } \\
\text { technology } \\
\text { software }\end{array}$ & $\begin{array}{l}\text { Localisation } \\
\text { Services }\end{array}$ & $\begin{array}{l}\text { Insurance } \\
\text { software }\end{array}$ & $\begin{array}{c}\text { Mobile and wireless } \\
\text { software }\end{array}$ & $\begin{array}{l}\text { Platform } \\
\text { software } \\
\text { technologies }\end{array}$ & $\begin{array}{c}\text { Fraud, } \\
\text { risk management } \\
\text { and } \\
\text { CRM software }\end{array}$ & $\begin{array}{l}\text { Logistics } \\
\text { management } \\
\text { software }\end{array}$ & $\begin{array}{c}\text { Online } \\
\text { accommodation } \\
\text { booking } \\
\text { software }\end{array}$ \\
\hline Founded & 1987 & 1994 & 1997 & 1997 & $\begin{array}{l}1993 \text { Rebranded } \\
2001\end{array}$ & 1999 & 1998 & 1998 & 1984 & 1999 \\
\hline $\begin{array}{l}\text { Began } \\
\text { Internationalising }\end{array}$ & 1998 & 1994 & 2000 & 1997 & 1994 & 1999 & 2002 & 1998 & 1985 & 1999 \\
\hline $\begin{array}{l}\text { Owner } \\
\text { Managed }\end{array}$ & $\begin{array}{l}\text { Manager } \\
\text { Joined } \\
2000\end{array}$ & Yes & $\begin{array}{l}\text { Manager } \\
\text { Joined } \\
2000\end{array}$ & Yes & Yes & Yes & Yes & Yes & Yes & Yes \\
\hline Employees & 70 & 40 & 25 & 150 & 210 & 24 & 30 & 50 & 80 & 37 \\
\hline $\begin{array}{l}\text { Initial domestic } \\
\text { Focus }\end{array}$ & Yes & No & Yes & No & No & No & Yes & Yes & Yes & No \\
\hline $\begin{array}{l}\text { Internationalisation } \\
\text { Trigger }\end{array}$ & $\begin{array}{l}\text { Unsolicited } \\
\text { Order UK }\end{array}$ & Client seeking & $\begin{array}{l}\text { Unsolicited } \\
\text { order }\end{array}$ & Client seeking & Client seeking & $\begin{array}{l}\text { Service existing } \\
\text { client }\end{array}$ & Client seeking & Client seeking & $\begin{array}{l}\text { Client } \\
\text { seeking }\end{array}$ & Client seeking \\
\hline $\begin{array}{l}\text { Internationalisation } \\
\text { Mindset }\end{array}$ & No & Yes & Yes & Yes & Yes & Yes & Yes & Yes & Yes & Yes \\
\hline $\begin{array}{l}\text { Internationalisation } \\
\text { Strategy }\end{array}$ & No & No & Yes & Yes & Yes & No & Yes & Yes & Yes & Yes \\
\hline $\begin{array}{l}\text { Overseas } \\
\text { Production }\end{array}$ & No & No & No & No & No & No & No & No & No & No \\
\hline Overseas Office & $\begin{array}{l}\text { Yes } \\
\text { UK }\end{array}$ & $\begin{array}{l}\text { Yes } \\
\text { US }\end{array}$ & $\begin{array}{l}\text { Yes } \\
\text { UK }\end{array}$ & $\begin{array}{l}\text { Yes } \\
\text { US }\end{array}$ & \begin{tabular}{c}
\multicolumn{1}{c}{ Yes } \\
Europe/US \\
Australasia
\end{tabular} & $\begin{array}{l}\text { Yes } \\
\text { Japan }\end{array}$ & No & $\begin{array}{c}\text { Yes } \\
\text { Benelux }\end{array}$ & $\begin{array}{l}\text { Yes } \\
\text { UK/US }\end{array}$ & $\begin{array}{c}\text { Yes } \\
\text { Australia }\end{array}$ \\
\hline
\end{tabular}



